\title{
THE RISK MANAGEMENT OF ISLAMIC TERRORISM IN A FRAGILE STATE: THE CASE OF MOZAMBIQUE
}

\author{
Luca Bussotti \\ International Studies Center, ISCTE-IUL, Portugal \\ Federal University of Pernambuco, Brazil \\ E-mail: Lbiau@iscte-iul.pt \\ Charles Torres \\ ISGE-GM, Mozambique \\ SMCU, Switzerland \\ E-mail: torrescharles96@gmail.com
}

\begin{abstract}
Islamic terrorism has been a serious threat for Eastern and Southern Africa since the 1990s. Many of these African countries have developed different forms of struggle against Islamic terrorism, from a military intervention to social policies, in order to improve the general socio-economic conditions for society as a whole. In Mozambique, no specific measure was adopted to cope the diffusion of terrorism, leaving that radicalized forms of Islamism spread in particular in Cabo Delgado, a Northern Province bordering with Tanzania. Research aimed at approaching Islamic terrorism in Cabo Delgado according to the strategy of risk prevention and risk management by Mozambican State. This study demonstrates that during the second term of Guebuza as a Chief of State, Mozambique had to face three different, potential threats. Nevertheless, Mozambican government identified two of these threats as a priority (namely Somali piracy in Mozambique Channel and Renamo's action), neglecting possible Islamic terrorist attacks in Cabo Delgado Province. This study demonstrates - using privileged witnesses as well as open sources available in the public sphere - that this choice was typical of a fragile and authoritarian State. Firstly, it was not based on an objective risk analysis, but on political as well as on patrimonial interests of political elite, and secondly local civil society could not oppose any resistance. This choice allowed radical Islamic groups to grow undisturbed in Cabo Delgado, until carrying out violent attacks from October 2017, which Mozambican government seems unable to counter until today.
\end{abstract}

Keywords: Cabo Delgado Province, Mozambican State, religious extremism, risk prevention.

\section{Introduction}

One of the main characteristics of Mozambique, as a national State, has always been a high level of religious tolerance and the lack of religious conflicts. The civil war between the government led by a single party, Frelimo, and Renamo (National Resistance of Mozambique, the main opposition party) lasted 16 years (1976-1992) and it is continuing until today, after more than 20 years of apparent peace; nevertheless, it never had religious motivations. This pacific cohabitation is demonstrated by the religious mosaic which characterizes this country, with about $53 \%$ of Christian faithful (with a prevalence of Catholic adherents), almost 19\% of Muslims and almost 30\% following traditional religions (ACN International, 2018). Muslims are concentrated in some Northern provinces, especially along the coast, as Nampula, Cabo 
PROBLEMS

OF MANAGEMENT

IN THE $21^{\text {st }}$ CENTURY Vol. 15 , No. 1,2020

Delgado, a part of Niassa and, in the South, in the capital Maputo. One could think that it is for this historical background that Mozambican government ignored systematically the signals of a new, religious threat coming from radicalized Islamic groups living in Cabo Delgado Province. Probably, this is just a small part of what is happening, and that Mozambican government had enormous responsibilities in underestimating a threat which was well known, due to a mix of political and financial reasons. In addition, Mozambique has been the last country, in Southern and Eastern Africa, which suffered extremist attacks, since countries as Tanzania, Kenya, Somalia passed from this situation since the 1990s.

The purpose of this research was to understand how Mozambican institutions have dealt with a new risk constituted by the Islamic terrorism, considering three fundamental elements: 1 . The political and military management of this situation, under the optic of risk prevention and mitigation; 2. The strategic decisions of Mozambican government in front of the multiple risks which the country had to face and manage, especially from 2013-2014; 3. The contradictions showed by the risk analysis and management by Mozambican government, which permitted the diffusion of a terroristic war in Cabo Delgado Province.

The main hypothesis was that, starting from the beginning of the 2010s, Mozambican government did not consider the Islamic terrorism as a strategic risk, privileging other, supposed threat. This attitude made Mozambican government as the main entity responsible for the diffusion of Islamic extremism in Cabo Delgado Province. The two main determinants for explaining this attitude have to be found in two structural characteristics of Mozambican State: fragility and authoritarianism.

\section{Managing Islam: A Short Historical Overview}

In order to understand why religious issues could not be considered as a threat for Mozambique, it is worth offering a short overview of Islam in this country.

Mozambican authorities have dealt with religious issues in various manners according to different historical epochs. Immediately after its political independence, in 1975, Mozambique opted for a socialist organization of the State (officially from its adhesion to MarxismLeninism, in 1977 until the approval of a new democratic Constitution, in 1990). According to its 1975 Constitution, religion was permitted as a private option, but, as a matter of fact, it suffered significant restrictions. This was especially the case for the Catholic Church, which was considered as a tool directly linked to the former colonial power, Portugal. Consequently, the state proceeded to a wave of nationalizations which included religious properties during this first period of independence (Decree n. 5/76), as well as persecutions against representatives of traditional religions (curandeiros), considered as "obscurantists" and largely deported. Deportations into the "reeducation camps" in the North of the country, especially Niassa, were practiced against political dissidents, traditional chiefs and representatives of some religions, especially Jehovah's Witnesses (Thomaz, 2008).

Despite this general approach towards religious issues, Mozambican socialist government tried to establish - at the beginning of the 1980s - a favourable relationship with its Islamic community. Islam had penetrated in Mozambique since the $8^{\text {th }}$ century, and the Portuguese regime tried to use the most ancient Muslim group in Northern Mozambique, that of Sufi, in detriment of a more urban Islam, that of Wahhabism, formed in Mozambique in the 1960s by Indian-Mozambican people, with its central base in the Lourenço Marques Anuaril mosque (Bonate, 2007). Some Northern brotherhoods resisted to the Portuguese occupation, participating actively to the struggle for liberation carried out by Frelimo. The reason of this political option has to be found in the persecution of Portuguese colonization against Muslims as well as in the support of Tanzanian TANU (Tanganyka African National Union) to Frelimo. TANU was largely composed by Muslims, which served as a "bridge" with Frelimo and its struggle for the liberation of Mozambique. 
Nevertheless, after the constitutional changes in 1978-79 (Nhaueleque, 2018), the two Mozambican Islamic tendencies formed a unique Islamic association, in order to face the new legal and political situation. In 1981 an Islamic Council of Mozambique was constituted in Maputo, naming Abubacar Ismael "Mangira" as its first president (Bonate, 2007). Nonetheless, the great influence of the modern ideology of Wahhabism as well as the preference for this tendency by the single party government led by Frelimo caused a split inside the Council, inducing the Sufis to create an independent organization, called Islamic Congress of Mozambique, in 1983. Until today, this division exists, with a significant presence of the Islamic Congress in Northern Mozambique and a close link with small brotherhoods, traditional chiefships and local authorities, expressing a political tendency in opposition to Frelimo's power. On the contrary, the Islamic Council continues to be dominated by rich Asian-Mozambican chiefships, which are strongly present in the South, especially in Maputo. The Islamic Council maintains deep political and economic connections with Frelimo. Some of its main laic representatives, from the 1990s, entered the dominant Frelimo's elite in key institutional and business positions (Morier-Genoud, 2007), as in the case - just to remember the most recent ones - of Gabriel Salimo, Ministry of Science of Technology, Abdul Carimo, President of the National Electoral Committee and Salimo Abdul, CEO of Vodacom Mozambique, a close friend and sponsor of the former President Armando Guebuza, with whom he shared the ownership of the social capital of Intelec, a company acting in the field of telecommunication (Moçambique/Dívidas, 2019).

The two main Islamic groups above mentioned are not only different for their ethnic origins - the Council composed broadly by members of Asian origins, the Congress by people of African origins -, but also for their economic conditions and political tendencies.

Subsequently, it is not surprising that attacks of Islamist leaning have been carried out by radical groups historically excluded from Frelimo's power system in the North of the country. In October 2017, the $5^{\text {th }}$, the first attack was directed against a police station by an unknown group of supposed Islamic terrorists in Mocimboa da Praia, North of Cabo Delgado Province. This attack occurred near the gas extraction fields of Afungi by multinational societies as Anadarko, Total, ENI, Exxon, Galp, and so on. This was an unexpected fact. Since then, attacks continued, provoking some hundreds deaths (probably near 1000). This stimulated a public debate that, till now, focused on the causes of this unexpected wave of attacks rather than on the contradictions demonstrated by Mozambican government in the management of this phenomenon.

As in the case of the first attack, during the following ones, Mozambican institutions, including army, have always been surprised. This is an inexplicable situation, more yet if one thinks that the area nearby the terroristic attacks became a sensible target, due to the great investment in gas approved by Mozambican State (Elliott, 2010). The delay in the final investment decision by Exxon-ENI - in part due to these terroristic attacks - is provoking serious losses for Mozambique. Nonetheless, Mozambican government has continued to adopt an approach which gave a considerable military vantage to the rebels in Cabo Delgado Province.

\title{
Theoretical Framework
}

An epistemological presupposition determined the option for the object of research here presented: the need to escape a perspective whose aim was to establish the cause(s) of a complex process like Islamic terrorism in Mozambique, far away from a positivist and mechanist perspective. A comprehensive approach has been the main epistemological option. This approach considers a vast array of relationships among different social actors, according to a theory of action focused on the identification of the rationale, the interests, weakness and contradictions of each participant to the social and political game (Marini \& Singer, 1988; Hedström \& Yilikoski, 2010). For, the analysis of Mozambican government before the risk of terrorism in Northern Mozambique permitted to avoid speculations at the moment not

\author{
PROBLEMS \\ OF MANAGEMENT \\ IN THE $21^{\text {st }}$ CENTURY \\ Vol. 15 , No. 1, 2020 \\ 11
}


PROBLEMS

OF MANAGEMENT

IN THE $21^{\text {st }}$ CENTURY Vol. 15 , No. 1,2020

12

corroborated by evidences on the nature, objectives, compositions, and financial resources of these extremist groups, whose identity remains unknown. Such approach is similar to that adopted in some research carried out in other African countries on terrorism, which emphasized the role of the State in the struggle against radical Islamist groups (Dowd, 2015), as well as the role of the institutional fragility, which contributes to the lack of capacity to prevent and manage effectively terrorist attacks (Worcester, 2015).

Coherently with the epistemological perspective, the theoretical framework here used is that of political risk. It has to be conceptualized as the ability of an entity (in this case a national State) to foster strategic risks, managing and copying them effectively (Bussotti, 2014). In Africa, political risk has been approached, in the last few years, as one of the most important factors for the development of the whole continent and related to Foreign Direct Investments (FDI) (Boga, 2019). According to a research carried out in 22 Sub-Saharan African countries, the main factors which constrained the implementation of FDI in Africa were corruption and political instability, besides macroeconomic instability, weak infrastructures and so on (Asiedu, 2006). It means that, once Mozambique became the target for big FDI in gas exploration, the local government had to implement a strategy of risk prevention and mitigation to guarantee this strategic investment, as well as to protect local populations from possible terroristic attacks. Furthermore, the risk for FDI, today, is more focused on terroristic attacks rather than on programs of nationalizations, as it occurred between the 1950s and 1970s (Jarvis \& Griffiths, 2007), and Mozambique's position in the Risk Index in Africa is very high, in the top-10 countries (COFACE, 2018).

This perspective of risk prevention embedded into the management of fundamental economic axis is yet more interesting if one thinks of Mozambique as a fragile State. Institutional fragility presupposes a complex and multidimensional factor, including political, societal, economic, environmental and security dimensions (OECD, 2018). According to the Fragile States Index, Mozambique has been classified, in 2019, as a High Warning State, being one of the worst States in terms of performance during the decade 2009-2019 for this index (Fund for Peace, 2019). In particular, for the case of Mozambique institutional fragility has been associated to authoritarianism, characterized by the following features:

1. Centralization of power in the hands of the Chief of State: this is in part due to Mozambican Constitution and had, as its main consequence in Guebuza's era, the systematic exclusion of the opposition, as well as the marginalization of civil society from strategic decisions and from the control of the government actions (Batley et al., 2006; FDC, 2007);

2. Reduction of press and academic freedom (Bussotti, 2015; O'Laughlin, 2014);

3. Patrimonial State, permitting Gubuza and his family and acolytes to implement practices of personal enrichment, in detriment of the public interests (Braathen \& Orre, 2011), which oriented at least all the main strategic options during Guebuza's second term.

The purpose of this research was focused on how this condition of fragility and authoritarianism has influenced the risk perception, prevention and management regarding Islamic terrorism by Mozambican State. It is not the first case that a fragile African State had to face a similar threat. In Western Africa as well as in the Horn of Africa or in Austral Africa (to which Mozambique belongs too) various States adopted different approaches to this phenomenon (Lyman, ND). Nonetheless, international cooperation in the military as well as in the intelligence field represented a key option to face Islamic terrorism. On the contrary, Mozambique rejected systematically this option, until the beginning of 2020, when two private security companies were contracted to fight against Islamic terrorists in Cabo Delgado Province. 


\section{Research Methodology}

The research here presented was carried out through a qualitative approach. Its main tools have been the following: firstly, a bibliographic analysis of the scarce material available for this topic, including some interviews realized with various actors and observers in place as well as in international newspapers; secondly, institutional sources and privileged witnesses, in order to understand the position of Mozambican government in relation to the subject here studied; finally, privileged oral sources belonging to Mozambican Intelligence Service (SISE), Mozambican Army and Police. A very important source was a Muslim preacher currently living in Maputo but born in Nampula, with deep contacts with Islamic groups in Northern Mozambique. This source not only made available confidential information, but used his network of contacts in Northern Mozambique, which permitted to have a credible overview of Islamic radical movements in the 2010s, that is the relevant period for this research. In addition, many other informal sources were heard, in order to cross the information previously collected.

All the oral sources accepted to be interviewed under the condition of anonymity, because of the sensitive issue approached in this study. For, in a State like Mozambique, the approach to risk communication is very confidential, omitting regularly important information to its citizens. Oral sources were previously informed that their information would have been used for carrying out a scientific research and not for political reasons.

\section{The State of the Art: Approaches to Islamic Terrorism in Cabo Delgado Province}

Studies on the way in which Mozambican government dealt with Islamic terrorism are rare, although their number tended to increase in the last few years. Some studies realized by international agencies and centres of research at the beginning of the 2010s considered that the risk of an Islamic insurgency in Mozambique was low. On the contrary, confidential reports of some intelligence services, including that of Mozambique, revealed that since the 2010s there was a high threat of Islamic extremism in Northern Mozambique.

The first analysis carried out under the perspective of political risk was realized by two researchers of the Chatham House, an English institute of international relations among the most prestigious in the world (Astill-Brown \& Weimer, 2010). Here, the authors made a photograph of some possible risks in Northern Mozambique, showing a too optimistic view of the real situation. According to them, porous boundaries, together with "weak governance and the collaboration of elites with transnational criminal networks" could determine a serious risk of an Islamic insurgency. This statement would have been corroborated by an important presence of South-Asian Muslim immigrants in the North of the country, who could use Mozambique as a "transit point" for terroristic actions (Astill-Brown \& Weimer, 2010, p.IX). Nevertheless, this risk was assessed as "low", due to the fact that Islam community in Mozambique was closely entrenched with local political elites. For, the authors classified as unlikely a possible process of radicalization of Muslims which are also Frelimo's members. Astill-Brown thought that Muslims in Cabo Delgado stood for Frelimo and were rich and business people, meanwhile only a strict elite of these Islamic members in Cabo Delgado met such conditions. All the others, mainly belonging to Kimwani and Makhwas ethnic groups, were poor people with no sympathy for Frelimo and Mozambican government, in contrast with the official Islam of the Islamic Council of Mozambique (CISLAMO) and of African origins. It was this large group of Muslims, historically marginalized and out of the political and business circuit dominated by individuals of Makondes ethnicity that in 2017, started armed attacks against official institutions.

Starting from 2018 other studies referred to a different situation. Local witnesses showed that the first signs of a different Islam in Cabo Delgado would date to 2014-2015, in Mocimboa da Praia. According to three local Islamic leaders, called "Sheik", young people who before 
Luca BUSSOTTI, Charles TORRES. The risk management of Islamic terrorism in a fragile state: The case of Mozambique

PROBLEMS

OF MANAGEMENT

IN THE $21^{\text {st }}$ CENTURY Vol. 15, No. 1, 2020

14 doctrine and with Mozambican institutions, helped by radical people coming from Congo, Uganda, Tanzania and Kenya. They spread a different, extremist Islam, based on the imposition of Sharia to all people (Matsinhe \& Valoi, 2019). What is more interesting for this research, is that "the authorities were warned about the phenomenon, but they chose inaction and turned a blind eye, until they were rudely awakened and shaken in October 2017" (Matsinhe \& Valoi, 2019 , p. 8). To understand the reasons of this inaction is one of the objectives of the next point.

A similar perspective was shared by another research, whose author stated that the extremist group of Ahlu Sunnah Wa-Jamo (ASWJ) had been formed, in Mozambique, in 2015, headed by Nur Adremam and Jafar Alawi, both from Mocimboa da Praia and probably influenced by Aboud Rongo, a radical Muslim prayer, who died in 2012 in Somalia and with a passage into Mozambique (Swart, 2019). What Swart pointed out is that Mozambique "is considered a fragile State", lacking "a counterterrorism and insurgency capability, both in expertise and in equipment" (Swart, 2019, p. 11). According to Columbo, the factors of weakness mentioned above induced insurgents to think of an independent new national State including Northern Mozambique and Southern Tanzania, under a Sharia law (Columbo, 2019).

The main tendency in the studies on insurgency in Mozambique considered the origins of the ASWJ group as well as the cause of the attacks as the principal topics to be investigated. Nevertheless, as Bonate stated, it is difficult to establish the reasons which determined insurgency in Mozambique. Though, Bonate thought that the main reason for insurgency should be found in the politics of land grabbing carried out by Mozambican government in alliance with the great multinational enterprises at the time of their installation in Cabo Delgado for carrying out the business of gas extraction. She pointed out that land, for Kimaniand Makhwa Muslim populations, has always played an important role not only from an economic point of view, but also from a spiritual perspective. Despite violent contestations, Mozambican government ignored these claims, deepening a sentiment of exclusion and frustration which involved young people in Palma and Mocimboa da Praia (Bonate, 2018). Furthermore, the political, opposite tendencies between CISLAMO representatives and the young Muslims in Mocimboa da Praia - who stood for Renamo or manifested a general idiosyncrasy against Frelimo - could be a significant element of differentiation inside Mozambican Islam and a serious obstacle for the solution of the conflict in the North of the country (Bonate, 2019).

If Bonate suggested a good dose of caution approaching insurgency in Cabo Delgado and its causes, other studies were more explicit in trying to establish a direct relationship between socio-economic factors and insurgency. For instance, Habibe, Forquilha and Pereira thought that poverty and lack of work represented the main reason to explain the adhesion of young people to the extremist groups operating in Mocimboa da Praia (Habibe et al., 2019). Another study tried to investigate the social and economic reasons which have induced some of the young population in Cabo Delgado to adhere the message of the Islamic extremists, formulating an agenda for a future pacification (Pirio et al., 2018); the above mentioned research of Matsinhe and Valoi stated that socio-economic factors could have a decisive importance in dictating the choice of an armed insurgency. They pointed out that Cabo Delgado was the worst Mozambican province in terms of post-secondary education (with only $0.3 \%$ of local population having an academic diploma), as well as in terms of school attendance in individuals between 5 to 25 years (with only 35.\% regularly enrolled at school). Someone spoke of Cabo Delgado as "Cabo Esquecido" (Forgotten Cape) (Matsinhe \& Valoi, 2019).

Nevertheless, this last approach is not decisive, since it is impossible to establish a direct relation between poorness and insurgency, even if the socio-economic situation could be one of the main factors for the diffusion of Islamic terrorism. This epistemological approach, embedded in a positivist perspective, cannot explain the complexity of a phenomenon with many nuances and shades. This is one of the reasons why we opted to see insurgency in Northern Mozambique from a different perspective, that of the risk assessment by the State. 


\section{Limits of Islamic Risk Perception in Cabo Delgado by Mozambican State}

According to the international debate previously reported, the first moment of "crisis" in Islamism of Cabo Delgado occurred in 2014-2015, when great investments on gas began to be operative. The question that begs to be answered is the following: which factors contributed to determine the myopia of Mozambican institutions towards this phenomenon? And, in addition, was Mozambican intelligence completely in the dark, or its warnings to domestic decisionmakers have been ignored?

According to the various privileged witnesses interviewed, sufficient pieces of information have always been available to Mozambican government in relation to the risk represented by Islamic extremism in Cabo Delgado, since 2010. Differently from the Chatham House analysis mentioned above, intelligence services had reported confidential information which could induce Mozambican government to manage this high risk in accordance with the basic principles of risk prevention.

The first attempt to radicalize Nampula and Cabo Delgado provinces had been carried out by an important extremist preacher, Sheik Zuneid, known as "Big Zito", who acted since 2003. According to oral sources, he was probably the first to have challenged official Islam all over the country, but especially in Mocímboa da Praia and Chiuré and in the Expansion zone in Nampula City. Big Zito was expulsed from Hamza Institute of Matola (Maputo Province), an Islamic institution for religious training, but he continued to preach in small mosques in Northern Mozambique, before coming back to Tanzania, where he probably joined a radical group of Al-Shabaab in Iringa District, at the Abdul Aziz College.

Oral sources confirmed that CIA, since 2010, informed SISE that in Cabo Delgado province the first group of jihadists had been influenced by some religious radical leaders. In 2012, CISLAMO - during the celebration of the 20th anniversary of the General Peace Agreement of Rome - revealed the existence of Madrassas in Mocímboa da Praia where some men were receiving military trainings. Probably, the trainers were some Tanzanian extremists coming from the Abdul Aziz College, where the indoctrination of a radical Islam was associated with the practice of Karate. In the same year, many young Muslims were recruited to go to study in the Middle East, in particular in Saudi Arabia, but also in African countries, as Egypt and Sudan. Only in Saudi Arabia the pupils passed from an academic training, meanwhile in Egypt and Sudan the training was focused on a theological field at a pre-academic level. The process of radicalization found its first external manifestations after that the young Muslims came back to Mozambique, spreading doctrines of a new, purified Islam, and considering the other faithful as infiltrated of the authentic Islam and thus infidel. They dressed black tunics, proposing the adoption of Sharia.

SISE produced a report submitted to the Presidency of the Republic - in that epoch Armando Emílio Guebuza, in charge until 2014 - and analysed by the Defence and Security Council (an advisory organism subordinated to the President of the Republic). Today, the same President of CISLAMO, Sheik Aminuddin Muhammad, remembered the attitude of passivity of Mozambican institutions in the past years, when CISLAMO informed them of a consistent risk of radical groups acting in Cabo Delgado Province (Nhampossa, 2020). The conclusion was that it was an internal conflict inside local Islam, so that the State had to avoid any intervention, because of its laicity. The institutional risk analysis concluded that this risk was very low, and that it could not be considered as a strategic threat.

This process of radicalization suffered a dramatic acceleration in 2015-2016. The first coastal district to show clear manifestation of Islamic radicalism was Macomia, in the locality of Pangane. Here, religious leaders banned the sale of alcoholic drinks, prohibiting pupils to attend school. The local newspapers Notícias and Domingo, in 2015, reported that some religious leaders of Pangane destroyed local commercial establishments, with the backing of a part of the local population. 
PROBLEMS

OF MANAGEMENT

IN THE $21^{\text {st }}$ CENTURY

Vol. 15 , No. 1,2020

Domingo pointed out that Pangane was a locality out of the ordinary, with laws established by religious Islamic leaders. In addition, Domingo stated that local Muslims rejected the local chief for being Makonde and Christian. The dominance of Islam in Pangane was confirmed by the fact that other religious confessions could not find any expression there. For instance, God Assembly leaders had to leave the region, due to the lack of adherents.

In 2016, the local chief of Quiterajo expressed compliances in relation to some Muslim leaders, who had been able to provoke a school dropout of more than half of the students of Escola Primária Completa of Pequeué, who passed attending school in local Madrassas.

Local population tried to respond to the diffusion of Islamic radicalism. In October 2016, some inhabitants of Coglo village, in the administrative post of Mucojo, destroyed a mosque of radical tendency, accusing its leaders to be fundamentalist and to violate the principles of Islam. In December of the same year, the local authorities of Macomia District signalled the presence of Al-Shabaab members there, inviting the population to reject such ideas and addressing a warning to national authorities in order to combat firmly this group.

The first attack carried out by this group occurred in Intutupué, in July 2016, against a mosque. This attack was reported to SISE and to local government by Saide Bacar, a Muslim leader member of CISLAMO.

There was a separation between the Islamic moderate wing members of CISLAMO and a new sect which was penetrating some districts in Cabo Delgado. This sect was created in Kenya, where they tried to build a local caliphate. After that Kenyan authorities expulsed many members of this sect, they got shelter in Tanzania (Zanzibar). Here too, local authorities drove out them; it was only in Cabo Delgado that this group found a fertile soil for action.

At the same time, Mozambican authorities identified two other possible threats. The first one was represented by the traditional government's enemy, Renamo. The second one was a new threat of some supposed Somali pirates acting in Cabo Delgado coast. They were simple Somali fishers escaped from Somali war and who carried out first attacks to boats in Northern Mozambique. They were not connected with radical projects. Hence, a new idea appeared: the need of a marine protection of Mozambican coastline. A multi-sectorial commission was named. It was headed by the Ministry of National Defence (MDN), which constituted a new public company in 2007, Monte Binga, under the tutelage of the Ministry of National Defence, as explained below.

This was the central moment, for Mozambican State, to address its political attention as well as its financial resources towards one of the emergent threats:

1. Somalian pirates;

2. Renamo;

3. Islamic terrorists in the North of the country.

\section{The Wrong Options and Their Consequences}

The political atmosphere during the second Guebuza's term, from 2009 to 2014, was a decisive element for understanding why Mozambican government failed in identifying the most serious risk among the three here considered.

Guebuza has been considered as the most authoritarian Chief of State after the introduction of a democratic system in Mozambique in the 1990s, as well as a political figure able to build a business empire thanks to its institutional position (Hanlon \& Mosse, 2010). Since his first electoral campaign, he proposed a nationalistic ideology, centred on the concept of sovereignty and Mozambican proud (Brito, 2009), with a quick approximation to China and other non-democratic countries, like Vietnam, Russia and some African States, as well as with new international players such as India and Brazil, cooling the relationships with Western countries (Anthony, 2015; Bussotti \& Macamo, 2018). During his second term, Guebuza 
accentuated his strategy of security, looking for threats which could facilitate his authoritarian project, defined by someone as an attempt of "fascistization" of the country (Rocha, 2014). Starting from this security strategy, Guebuza defined two great, linked fields of action: 1) to guarantee a national security to Mozambique, especially in the maritime field, in Mozambique Channel, traditionally patrolled by South African and French military ships and where Somali piracy was carrying out numerous attacks; 2) to guarantee the same security with regard to political stability, setting aside his traditional enemy, Dhlakama, and his party, Renamo.

All the risk analyses developed by Mozambican institutions between 2009 and 2014 were deeply influenced by this authoritarian and personal strategy of Guebuza. This is a typical behaviour of a fragile State, in which the "chief" is dominant in comparison with democratic institutions. In addition, Guebuza increased the patrimonial tendency of Mozambican State, with great thirst of enrichment for his own family, together with his acolytes (Reid, 2018).

1. Maritime Security, especially related to Mozambique Channel and Somali piracy. The phenomenon of Somali piracy in Mozambique Channel dates back to about 2006-2007. Since 2006-2007 a significant increment of the activity of piracy was detected all over the world. Nevertheless, between 2013 and 2015 the number of attacks dropped, thanks to a relevant maritime security surveillance (Gico Jr, 2016). SADC (Southern Africa Development Community) approved in Luanda in 2011 a proper strategy for the defence of maritime resources, known as SADC Maritime Security Strategy. Although, direct attacks against a member-State or the region as a whole were assessed as "a very remote possibility" (Coelho, 2013: 6). For the specific case of Cabo Delgado, new refugees and clandestine immigration from Somalia and other Eastern Africa States could increase the possibility of new attacks. As a consequence of the implementation of SADC Maritime Security Strategy, in Mozambique Channel a naval force leaded by a South African Defence Force (SANDF) conducted the Operation Copper, with very good results (MAST INTELLIGENCE, 2017). Nevertheless, the issue related to Somalian piracy changed dramatically in 2012-2013, with the discovering of great gas fields in Cabo Delgado. Firstly, Mozambican government aimed at implementing its own system of maritime surveillance of the Channel, overcoming the SADC system, which had developed a dependency from SANDF; secondly, the pressure of France was becoming too insistent to be accepted and was identified as a threat. France continues to control Mayotte Islands, small islands in Mozambique Channel, claimed from Comoro Islands. A draft of resolution of the United Nations had been voted in 1976, in order to return these islands to Comoro, but France exerted its veto right in the Security Council of UN and the resolution could not be voted. The same situation is observable in relation to the Scattered Islands, a property of France, claimed from Madagascar. Thus, France control of a consistent part of Mozambique Channel let preview some risks, for Mozambican State. In particular, Paris could demand the control for the offshore gas of Cabo Delgado, according to the rules of maritime international law. Before this complex situation, Mozambican government did not hesitate to move actions in order to arrange a system of protection of its maritime space. The occasion came when Jean Boustani, a FrenchLebanese businessman, close to President Guebuza and representative of Privinvest, one of the biggest shipbuilding companies in the world, organized a scheme of corruption based on the need of maritime security by Mozambican State. Three public companies were created between 2013 and 2014, ProIndicus, MAM and Ematum, controlled by companies belonging to MDN and to SISE - especially by Monte Binga company - and led by António Carlos do Rosário, the economic director of Mozambican intelligence. Mozambican State, in a secret financial operation authorized by the Minister of Finance, Manuel Chang, currently detained in South Africa, gave a warrant for 2,2 billion USD (about half of the Mozambican annual revenue) to allow these companies to order

\author{
PROBLEMS \\ OF MANAGEMENT \\ IN THE $21^{\text {st }}$ CENTURY \\ Vol. 15 , No. 1, 2020
}


PROBLEMS

OF MANAGEMENT IN THE $21^{\text {st }}$ CENTURY Vol. 15, No. 1,2020

18

Privinvest a shipbuilding for tuna fishing and patrolling Mozambique Channel. The two banks involved in this scheme were the Russian VTB - which, in 2020, filed a compliance against Mozambique - and the Swiss Credit, whose employees had an active role in developing the scheme of corruption. As a final result, Mozambique did not have any boat able to patrol Mozambique Channel. The Western countries which sustained Mozambican budget directly through a Budget Support initiative did not help Mozambique anymore, and many high bureaucrats of SISE as well as Mozambican politicians and Guebuza's family members were arrested all over the world for international corruption. In this case, a potential threat was transformed in an international scheme of corruption and individual enrichment, pauperizing Mozambican public budget and, hence, Mozambican people, while Guebuza's family continued to enrich.

2. Political Instability. The other, supposed threat that Mozambique was facing in the last few years of Guebuza's government was identified with Renamo. Historically, Renamo represented the traditional enemy of Mozambican government, since, immediately after the obtaining of its political independence, Renamo started a civil war with the financial aid of Rhodesia of Ian Smith and thus of the South African regime of apartheid. This war destroyed the county. After having obtained a General Peace Agreement in Rome in 1992, Renamo transformed itself into a political party, although maintaining its own army. Renamo participated in all the general elections, from the first ones in 1994. This party obtained good results and probably won the 1999 general elections, despite the official results (Hanlon, 2010). Frelimo always considered Renamo as an "intruder" in Mozambican life and, especially under Guebuza's government, it was identified as the main political threat for the country. Accordingly, many Renamo's representatives were detained without any legal basis, as in the case of its spokesman, Muchanga (Martins, 2014). In truth, the only threat constituted by Renamo was its electoral victory against Frelimo, and the consequent cleavage of Frelimo's power system, since Renamo did not have any possibility nor will to resume the war. Nevertheless, Guebuza was able to transmit the idea that Dhlakama and Renamo represented an actual threat for the country, imposing this line to his party, Frelimo, and to the government he leaded. Renamo's leader firstly changed from Maputo to Nampula, and thus to Gorongosa (Sofala Province), where he established his headquarters. In October 2013, the $21^{\text {st }}$, Mozambican military forces attacked Dhlakama's headquarters in Gorongosa, forcing him to find a new shelter. Since this date, the whole activity of SISE was directed to "hunt" Dhlakama, transforming him in the most serious threat for Mozambique, also after that a new Peace Agreement was signed between Guebuza and Dhlakama, and new general elections were celebrated in 2014. Renamo - which did not recognize the results, due to significant frauds - obtained good results, including the electoral majority in many Northern Provinces, as Nampula, Tete, Zambézia and Sofala. Before these results, Dhlakama began a campaign all over Mozambique, asking for a process of deep institutional reforms and claiming for all the provinces in which Renamo had won, but without significant results. The President of a Province, in that epoch, was named by the Chief of State, regardless for the electoral result; so, the new President, Nyusi, the successor of Guebuza, indicated for the role of President of all the Provinces figures belongings to Frelimo. Dhlakama was forced to come back to his headquarters in Sofala, where he died in 2018, May, the $3^{\text {rd }}$. This short description shows how Guebuza oriented the activity of SISE as well as of police and army towards an "invented" enemy and threat, Renamo. It became impossible to pay attention and thus to manage the other, very serious threat coming from Cabo Delgado, since it did not menace Frelimo's and Guebuza's power nor was attractive in terms of patrimonial scheme. 


\section{Conclusions}

The analysis here presented demonstrated how a fragile State as Mozambique dealt with a very serious and new threat, the Islamic terrorism in a Northern province of the country. The fragility of Mozambican State emerged when local authorities had to benchmark three possible risks. The criterion which oriented the risk calculation and management had nothing to do with strategic reasons and institutional concerns. By the way, the much boasted national interest defended by Guebuza was transformed into opportunities to accentuate his tendency to authoritarianism (in the case of Renamo's threat) and personal and family enrichment (in the case of maritime security in Mozambique Channel), neglecting the risk represented by Islamic terrorism, able to destabilize the whole country. A risk which was very well known, thanks to the activity of SISE as well as to the information coming from Islam moderate members that the government received punctually since 2010-2011.

In addition, the experience of Eastern African countries like Kenya could demonstrate that international military and intelligence cooperation - in the case of Kenya with the USA - played a decisive role in the fighting against Islamic terrorism. After the bombing attacks in 1998 against the American embassy in Nairobi, Kenyan police was trained by the National Security Intelligence Service of the USA, and in 2003 Kenya established a series of antiterrorism units which became a reference point for all Eastern African countries. Mozambique could learn from Kenya's (and Tanzania's) lection; nevertheless, Mozambican government did not consider the Islamic terrorism as a consistent threat, leaving that religious extremism spread all over the North of the country, in particular in Cabo Delgado Province.

An interesting aspect that this research pointed out is this fragility as the main determinant for the institutional management of risk. As clearly shown along the research, Guebuza had a personal project for maintaining power through a constitutional reform. It was only thanks to an internal opposition inside Frelimo that this project could not be realized. Nonetheless, this influence was exerted especially during the decision process of succession, rather than along Guebuza's governance. Here, Guebuza's power was not attenuated by the intervention of Frelimo, as well as the institutional powers which had to counterbalance the decisions of the Chief of State. Under this respect, fragility played a decisive role in the risk prevention and management: Guebuza found fertile and free space to impose his point of view and his conception of country risk to all other institutions. This condition of an institutional fragility together with the weakness of Mozambican civil society, was decisive to influence strategic political options in Mozambique until today. And the underestimation of Islamic terrorism in Cabo Delgado, currently out of control, is only the most visible among these strategic consequences.

\section{References}

ACN International (2018). Religious freedom in the world. Report 2018. Königstein (Germany): ACN International. https://religious-freedom-report.org/wp-content/uploads/2018/11/ENGLISH_ RFR2018_low.pdf

Anthony, R. (2015). China and Mozambique: From comrades to capitalists. Politikon, 42(3), 431-432. https://doi.org/10.1080/02589346.2015.1105386

Asiedu, E. (2006). Foreign investment in Africa: The role of natural resources, market size, government policy, institutions and political instability. https://dx.doi.org/10.2139/ssrn.717361

Astill-Brown, J., \& Weimer, M. (2010). Mozambique. Balancing, development, politics and security. Chatham House.

Batley, R., Bjørnestad, L., \& Cumbi, A. (2006). Mozambique county report. University of Birmingham. https://www.oecd.org/countries/mozambique/43867765.pdf

Boga, S. (2019). Determinants of foreign direct investments: A panel data analysis for Sub-Saharan Countries. Emerging Market Journal, 9(1), 80-87. https://doi.org/10.5195/emaj.2019.175 
Luca BUSSOTTI, Charles TORRES. The risk management of Islamic terrorism in a fragile state: The case of Mozambique

PROBLEMS

OF MANAGEMENT

IN THE $21^{\text {st }}$ CENTURY Vol. 15, No. 1, 2020

Bonate, L. (2007). Islam and chiefship in Northern Mozambique. ISIM Review, 19, 56-57.

Bonate, L. (2018). Islamic insurgency in Cabo Delgado: Extractive industry, youth revolt and global terrorism in Northern Mozambique. https:/www.academia.edu/38523976/Islamic_Insurgency_ in_Cabo_Delgado_Extractive_Industry_Youth_Revolt_and_Global_Terrorism_in_Northern_ Mozambique A Hypothesis

Bonate, L. (2019). Why the Mozambican's government alliance with the Islamic Council of Mozambique might not end the insurgency in Cabo Delgado. Zitamar News, 14/06/2019. https://zitamar.com/ mozambican-governments-alliance-islamic-council-mozambique-might-not-end-insurgencycabo-delgado/

Brito, L. de (2009). Discurso político e pobreza em Moçambique: análise de três discursos presidenciais [Political Discourse and poverty in Mozambique: An analysis of three presidential discourses]. Conference Paper N. 8. IESE. http://www.iese.ac.mz/lib/publication/II_conf/CP8 2009 Brito. pdf

Braathen, E., \& Orre, A. (2011). Can a Patrimonial State survive? The case of Mozambique. Forum for Development Studies, 28(2), 199-239. https://doi.org/10.1080/08039410.2001.9666169

Bussotti, L. (2014). The risk of current political risk management. Problems of Management in the $21^{\text {st }}$ Century, 9(3), 170-172.

Bussotti, L. (2015). Media freedom and the transition era in Mozambique: 1999-2000. In: Bussotti, L., Barros, M., \& Gräz. (Eds.). Media freedom and right to information in Africa, (pp. 45-71). Lisbon: CEI-ISCTE. https://books.openedition.org/cei/145

Bussotti, L., \& Macamo, E. (2018). A cooperação bilateral Brasil-Moçambique, com enfoque especial na Área da Defesa [The bilateral cooperation Brazil-Mozambique, with a special emphasis in the area of defense]. Cadernos de Estudos Africanos, 36, 113-136. https://journals.openedition.org/ cea $/ 3243$

Coelho, J. P. B. (2013). African approach to maritime security: Southern Africa. Fredrich Ebert-Stiftung.

COFACE (2018). Political risk in Africa: The temperature is rising. https://www.coface.com/NewsPublications/Publications/Political-risks-in-Africa-the-temperature-is-rising

Columbo, E. (2019). Northern Mozambique at a crossroad. CSIS.

Dowd, C. (2015). Grievances, governance and Islamist violence in sub-Saharan Africa. The Journal of Modern African Studies, 53(4), 505-531. https://doi.org/10.1017/S0022278X15000737

Elliott, S. (2020). Delay to Rovuma LNG latest setback for Mozambique LNG sector. S\&P Global. https://www. spglobal.com/platts/en/market-insights/latest-news/natural-gas/040920-delay-to-rovuma-lng-latest-setbackfor-mozambique-lng-sector

FDC (2007). Mozambican civil society within: Evaluation, challenges, opportunities and actions. FDC/ CIVICUS. https://www.civicus.org/media/CSI_Mozambique_Country_Report.pdf

Fund for Peace (2019). Fragile States Index. https://fragilestatesindex.org/

Gico, Jr., I.T., \& De Souza Delgado, J. (2016). Pirataria marítima: da segurança da navegação à responsabilidade do transportador internacional de mercadorias [Maritime piracy: From security in navigation to the responsibility of the international carrier of goods]. Cadernos do Programa de Pós-Graduação em Direito PPGDir/UFGS, 116-143.

Habibe, S. Forquilha, S., \& Pereira, J. (2019). Radicalização Islâmica no Norte de Moçambique [Islamic radicalization in Northern Mozambique]. Cadernos IESE, 17/2019. IESE. http://www.iese.ac.mz/ wp-content/uploads/2019/09/cadernos_17.pdf

Hanlon, J. (2010). Frelimo landslide in tainted elections in Mozambique. Review of African Political Economy, 37(123), 92-95. https://doi.org/10.1080/03056241003638019

Hanlon, J., \& Mosse, M. (2010). Mozambique's elite - Findings its way in a globalized world and returning to old development models. UNU-WIDER. https://www.rrojasdatabank.info/wp2010105.pdf

Hedström, P., \& Yilikoski, P. (2010). Causal mechanisms in the social sciences. Annual Review of Sociology, 36(1), 49-67. https://doi.org/10.1146/annurev.soc.012809.102632

Jarvis, D., \& Griffith, M. (2007). Learning to fly: The evolution of PR analysis. Global Society, 21(1), 5-21. 
Lyman, P. N. (ND). The war on terrorism in Africa. https://www.cfr.org/content/thinktank/Lyman chapter_Terrorism.pdf

Marini, M. M., \& Singer, B. (1988). Causality in the social sciences. American Sociological Association, 18, 347-409.

Martins, M. (2014). Moçambique: porta-voz da Renamo já em liberdade [Mozambique: Renamo spokesperson now free]. RFI. http://www.rfi.fr/pt/africa/20140819-mocambique-porta-vozda-renamo-ja-em-liberdade

Mast Intelligence (2017). Piracy threat in the Mozambique channel increases as operation copper is reduced to an electronic listening operation. http://www.mast-security.com/i/Downloads/Op Copper_Intrep.pdf

Matsinhe, D., \& Valoi, E. (2019). The genesis of insurgency in Northern Mozambique. Pretoria: Institute for Security Studies. https://issafrica.org/research/southern-africa-report/the-genesis-ofinsurgency-in-northern-mozambique

Moçambique/Dívidas: empresário Salimo Abdula admite "grande deceção" se caso afetar ex-PR [Mozambique/Debts: Bussinessman Salimo Abdula admits "great disappointment" if the case affects the former PR]. Lusa, 20/04/2019. https://www.dn.pt/lusa/entrevista-mocambiquedividasempresario-salimo-abdula-admite-grande-dececao-se-caso-afetar-ex-pr--10816664.html

Morier-Genoud, E. (2007). A prospect of secularization? Muslims and political power in Mozambique today. Journal for Islamic Studies, 27, 240-275. https://doi.org/10.4314/jis.v27i1.39936

Nhampossa, A. (2020). Governo não ligou aos avisos - sheik Aminuddin [Government did not give importance to the warnings - sheik Aminuddin]. Savana, 17/04/2020.

Nhaueleque, L. A. (2018). Os Direitos Humanos nas Constituições de Moçambique[Human Rights in Mozambican Constitutions]. In: Bussotti, L., \& Castiano, J.P. (Eds.). Participação da juventude $e$ das mulheres nos processos eleitorais [Participation of youth and women in the electoral processes] (pp. 105-126). OXFAM Moçambique.

OECD (2018). States of Fragility 2018. Paris: OECD. https://www.oecd.org/dac/conflict-fragilityresilience/docs/OECD\%20Highlights\%20documents_web.pdf

O'Laughlin, B. (2014). The political peril of criminalising academic freedom in Mozambique. Pambazuka. https://www.pambazuka.org/activism/political-perils-criminalising-academicfreedom-mozambique

Pirio, G., Pittelli, R., \& Adam, Y. (2018). The emergence of violent extremism in Northern Mozambique. African Center for Strategic Studies. https://africacenter.org/spotlight/the-emergence-of-violentextremism-in-northern-mozambique/

Reid, C. (2018). Mozambique: The anatomy of corruption. The Africa Report, 26/06/2018. https://www. theafricareport.com/607/mozambique-the-anatomy-of-corruption/

Rocha, J. M. (2014). Guebuza está a querer fascistizar o país. [Guebuza is aiming at getting Mozambique fascist] Público, 02/03/2014. https://www.publico.pt/2014/03/02/mundo/entrevista/deixaramcrescer-as-plantas-e-agora-querem-cortar-1626313

Swart, J. (2019). Countering Ahlu Sunnah Wa-Jamo (Al-Shabaab) Insurgency in Mozambique. ITCT.

Thomaz, O. R. (2008). "Escravos sem dono": a experiência social dos campos de trabalho em Moçambique no período socialista ["Slaves without master": The social experience of the work fields in Mozambique during the Socialist period]. Revista de Antropologia, 51(1), 177-214. http://taurus. unicamp.br/bitstream/REPOSIP/106048/1/2-s2.0-84859519439.pdf

Worcester, M. (2015). Combating terrorism in Africa. ISPSW. https://www.files.ethz.ch/isn/50103/ Combating_Terrorism_Africa.pdf 
Luca BUSSOTTI, Charles TORRES. The risk management of Islamic terrorism in a fragile state: The case of Mozambique

PROBLEMS

OF MANAGEMENT

IN THE $21^{\text {st }}$ CENTURY

Vol. 15 , No. 1,2020

Cite as: Bussotti, L., \& Torres, C. (2020). The risk management of Islamic terrorism in a fragile state: The case of Mozambique. Problems of Management in the 21 $1^{\text {st }}$ Century, 15(1), 9-22. https://doi.org/10.33225/pmc/20.15.09

Luca Bussotti

(Corresponding author)
PhD, International Studies Center, ISCTE-IUL, Lisbon, Portugal. Federal University of Pernambuco, Recife, Brazil.

E-mail: Lbiau@iscte-iul.pt

ORCID ID: https://orcid.org/0000-0002-1720-3571

ISGE-GM, Mozambique.

PhD Candidate at SMCU, Switzerland.

E-mail: torrescharles96@gmail.com 